\title{
Decreased insect visitation to a native species caused by an invasive tree in the Cape Floristic Region
}

\author{
Michelle R. Gibson ${ }^{\text {a }}$, Anton Pauw ${ }^{\mathrm{b}}$, David M. Richardson ${ }^{\mathrm{a}, *}$ \\ ${ }^{a}$ Centre for Invasion Biology, Department of Botany E Zoology, Stellenbosch University, 7602 Matieland, South Africa \\ ${ }^{\mathrm{b}}$ Department of Botany E' Zoology, Stellenbosch University, 7602 Matieland, South Africa
}

\section{A R T I C L E I N F O}

\section{Article history:}

Received 29 November 2011

Received in revised form 7 July 2012

Accepted 10 July 2012

\section{Keywords:}

Acacia saligna

Apis mellifera subsp. capensis

Biological invasions

Competition for pollinators

Fynbos

Invasive plants

Plant-insect interactions

\begin{abstract}
A B S T R A C T
Flowering invasive plants can potentially reduce pollination rates in co-flowering native plant species by attracting shared flower visitors. We investigate the effect of a prolifically flowering invasive species, Acacia saligna (Fabaceae), on native insect-flower interactions in surrounding communities. We surveyed flower visitation to $A$. saligna and selected native species at invaded and uninvaded areas and assessed the extent of flower visitor overlap of A. saligna and native species across four sites in South Africa's Cape Floristic Region. Median visitation rates of bees and all insects were significantly lower to one native species (Roepera fulva) in both field seasons at the same site when $A$. saligna was present. This native species also had the highest flower visitor overlap with $A$. saligna which was driven primarily by the native honeybee, Apis mellifera subsp. capensis. Observational data showed that $A$. saligna inflorescences were visited most frequently by minute beetles and the native honeybee. Our findings indicate that native honeybees are important visitors to $A$. saligna, and that at least one native plant species experiences reduced flower visitation due to competition with $A$. saligna for honeybee visits. Flowering $A$. saligna could have widereaching effects on native plants by competing for visits from a super generalist flower visitor - the native honeybee - which may jeopardize the reproductive success of natives whose flowering time overlaps with that of A. saligna. Our study further highlights the importance of understanding the effect of a flowering invasive species on native species and the potentially important mutualism between $A$. saligna and honeybees.
\end{abstract}

(c) 2012 Elsevier Ltd. All rights reserved.

\section{Introduction}

Alien plants with showy floral displays are attractive to native pollinators and interact with co-flowering native plants, thereby becoming integrated into invaded ecosystems (Bartomeus et al., 2008; Geerts and Pauw, 2009; Lopezaraiza-Mikel et al., 2007; Memmott and Waser, 2002). Potential consequences of such integration include changes in native plant seed set, pollen deposition (Larson et al., 2006), pollinator abundance and diversity (Moroń et al., 2009), visitation rate (Bartomeus et al., 2008), or composition of the pollinator fauna (Muñoz and Cavieres, 2008). Previous studies have found evidence for facilitation of visitation to native plants (Moragues and Traveset, 2005) and increased pollinator richness and abundance (Bartomeus et al., 2008; Lopezaraiza-Mikel et al., 2007). However, a recent meta-analysis showed overall negative effects of flowering aliens on native plant pollination and

* Corresponding author. Address: Stellenbosch University, Department of Botany \& Zoology, Centre for Invasion Biology, Private Bag X1, Matieland, Western Cape, 7602 Matieland, South Africa. Tel./fax: +27 0218083711.

E-mail addresses: mishka.r.g@gmail.com (M.R. Gibson), apauw@sun.ac.za (A. Pauw), rich@sun.ac.za (D.M. Richardson). reproduction (Morales and Traveset, 2009), which can further negatively impact plant and pollinator diversity (e.g. Gaertner et al., 2009; Moroń et al., 2009; Traveset and Richardson, 2006). For this reason and many others, invasive species are considered a major threat to biodiversity worldwide (Pimm et al., 1995). Management efforts are underway in many parts of the world to mitigate the harmful effects of invasive species (Pyšek and Richardson, 2010). Removal of aliens often has beneficial effects on native elements of ecosystems, but unexpected and sometimes undesirable effects have also been reported where, for instance, alien plants have become important resources for native pollinators (Carvalheiro et al., 2008; Valdovinos et al., 2009). More information on such interactions is needed to improve our ability to plan and execute effective restoration operations. Long-term effects of widespread flowering alien plants are poorly understood, but both positive and negative effects could potentially alter the evolutionary trajectories of native species and communities through pollinator shifts (Johnson et al., 1998; Schlüter et al., 2009). Consequently, understanding how a flowering alien plant interacts with co-occurring native plants and pollinators is important for developing plans for effective management interventions. 
Though research on this subject has increased over the last decade (Traveset and Richardson, 2011), most work has focused on alien shrubs or herbaceous species (e.g. Impatiens, Lonicera, Lythrum, Solidago), whereas some of the most problematic invasive species in many parts of the world are trees (e.g. Acacia, Pinus) (Lamarque et al., 2011; Richardson and Rejmánek, 2011). Australian Acacia species are a globally important group of plants. Many species have been widely introduced for their practical use (e.g. timber, fodder, land restoration), and many of these species have become invasive (Richardson et al., 2011). Australian acacias were introduced to South Africa, starting in the mid nineteenth century, mainly for tannin production and dune stabilization (Poynton, 2009). Many invasive Acacia species are now classified as "transformers" (invaders that change the character, condition, form or nature of ecosystems over a substantial area relative to the extent of that ecosystem; Richardson et al., 2000b) in South Africa (Henderson, 2001). They can completely alter the composition and diversity of native plant assemblages (Gaertner et al., 2011), change nutrient cycles (Yelenik et al., 2004) and fire regimes (van Wilgen and Richardson, 1985), thus radically altering the structure and functioning of ecosystems where invasion levels are high.

Although most invasive Acacia species grow well in disturbed areas, some species (e.g. A. cyclops, A. longifolia, A. saligna) can grow interspersed with native species, for instance in the sandy soils of lowland fynbos vegetation (see Fig. 1) (Yelenik et al., 2004). Moreover, the flowering time of some invasive species overlaps with

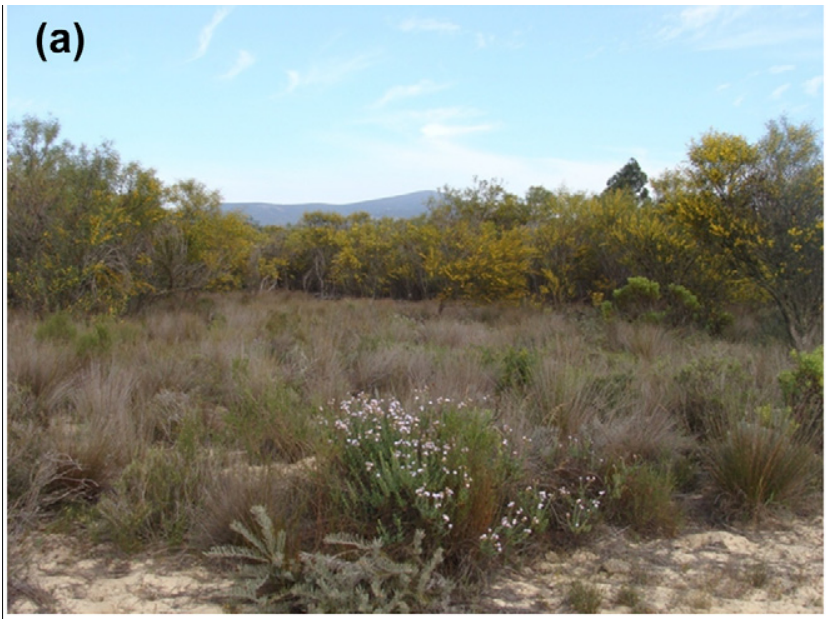

(b)

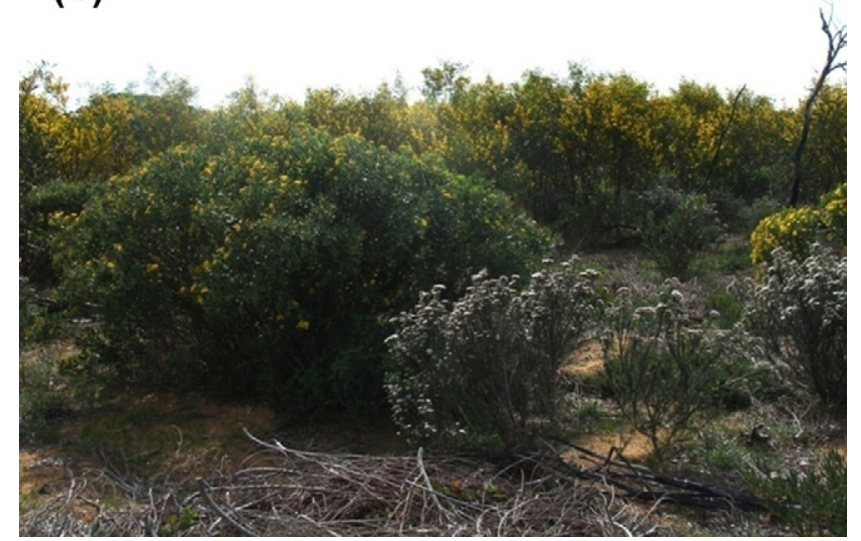

Fig. 1. (a) Floral display of Acacia saligna invading native fynbos vegetation in the Western Cape, South Africa (photo: A.M. Rogers). (b) Intermediate Acacia saligna invasion level in the background at the Koude Vlakte study site (photo: M.R. Gibson). that of many natives (Godoy et al., 2009). In many cases, the flower heads are long-lived with some able to last up to 2 weeks (George et al., 2009; Stone et al., 2003). Acacia species have a generalist floral morphology and form dense, bright floral displays during their flowering peak. In their native range, Australian acacias are visited most frequently by bees, wasps, flies and beetles (Bernhardt, 1989; Stone et al., 2003). Thus, there is a high potential for flowering acacias to interact with native communities via shared pollinators. Surprisingly, no studies have investigated the effect these species have on plant-pollinator relations in the communities they invade. Knowledge of such impacts can aid in the conservation of native plants and pollinators (Levy, 2011; Williams et al., 2010).

The aim of this study was to make a first assessment of the effect of a flowering invasive Acacia species on native plant-pollinator communities in South Africa. Specifically, we compare flower visitation and functional group composition of flower visitors to native species at sites where Acacia saligna is present and where it is absent. Visitation frequency has been shown to be an appropriate surrogate for both pollen transport (Alarcón, 2009) and the overall effect of animal mutualists on plant reproduction (Vázquez et al., 2005), and so may serve as a suitable first approximation of the overall effect of an invasive plant on native plant-pollinator communities. We also make the first assessment of visitors and visitation frequency to flowers of $A$. saligna in its introduced range, and calculate flower visitor overlap with native species. Due to its high abundance in many areas, its extensive, showy floral displays and easily accessible floral rewards (Gibson et al., 2011), we expected that $A$. saligna would likely compete with native species for flower visits on a community level as has been shown previously for other species (Taraxacum officinale-Muñoz and Cavieres, 2008; Real, 1983). Assuming that generalist insect foragers comprise a substantial portion of flower visitors to the invader (Memmott and Waser, 2002), we also expected that $A$. saligna would show at least moderate flower visitor overlap with native species.

\section{Material and methods}

\subsection{Study area}

The study took place in the south-western region of the Western Cape Province in South Africa's Cape Floristic Region (CFR). The CFR has one of the world's most diverse floras per unit area. The vegetation at our study sites is known as fynbos, and is dominated by species of Ericaceae, Proteaceae, and Restionaceae. The area receives about $500 \mathrm{~mm}$ of annual precipitation peaking in June through August, followed by the peak flowering season in spring (September-October) (Mucina and Rutherford, 2006). Mean summer and winter temperature extremes at our sites range from $27.9^{\circ} \mathrm{C}$ to $7.0^{\circ} \mathrm{C}$, respectively. Important pollinators of native plants include mainly native bees (e.g. the Cape honeybee, Apis mellifera subsp. capensis), flies, and beetles (e.g. monkey beetles Scarabaeidae: Rutelinae: Hopliini; Johnson, 2004).

The CFR also supports a high human density and so anthropogenic activities threaten much of its diversity, among which alien plant invasions are identified as the biggest threat (Rebelo, 2001; Rouget et al., 2003). Today invasive Australian acacias account for $36 \%$ cover of the lowlands in the Fynbos Biome (Rebelo et al., 2006). Our main study species is A. saligna (Labill.) H.L., an evergreen shrub or tree able to grow in sandy soils. Its bright yellow, globular inflorescences appear from August to November (Austral spring), and last up to 2 weeks (Stone et al., 2003). Despite major efforts to reduce the extent of invasive stands, especially over the past two decades (van Wilgen et al., 1994), A. saligna and several other Australian acacias still occur over tens of thousands of hectares (van Wilgen et al., 2011). Management of stands of invasive 
woody plants is one of the biggest challenges facing conservation managers in the CFR (Roura-Pascual et al., 2009).

\subsection{Sample design}

We carried out flower visitor observations at four different sites over the spring months (August-September) of 2009 and 2010 (Table 1), with one site (Koude Vlakte) surveyed in both years. We surveyed an additional site for $A$. saligna flower visitors where the dominant plant species were grasses and A. saligna thicket. At each site, we located an area of native vegetation invaded by $A$. saligna ('invaded') and an adjacent, non-invaded area of native vegetation to serve as the control plot ('uninvaded'). In the invaded plots A. saligna coexisted with native species and formed noticeable and widespread floral displays (Fig. 1b). Sites ranged in size from approximately $25-130$ ha in area. Invaded and uninvaded plots were more or less adjacent to one another with distances ranging from zero to $700 \mathrm{~m}$, and sites were located at least $5 \mathrm{~km}$ apart. We surveyed both plot types to determine which flowering native species were relatively the most common and/or widespread (hereafter referred as 'focal species'). At each site three focal species were identified. Due to high levels of beta diversity in fynbos there was no overlap among sites in focal species. Ideally the same focal species should be present at different sites to account for site-specific differences that may influence insect visitation. Because focal native species are not replicated across study sites, results should be interpreted with caution.

\subsection{Flower visitor observations}

Visitor observations for each of the focal plant species were 'paired', and carried out simultaneously (within 30 min of one another) by two observers at invaded and uninvaded plots, to ensure constant climatic conditions. We conducted observations from roughly 08:00 until 17:00. Each focal species was observed at three different locations within a plot, located at least $60 \mathrm{~m}$ away from one another to reduce the influence of local effects. Observation times were rotated so that all three focal species were observed once per day during a different time period (08:00-11:00 = 'AM', 11:00-14:00 = 'MD', 14:00-17:00 = 'PM') to account for temporal variation of flower visitation. Each observation lasted 15-30 min so that each focal species was observed for a total of $90 \mathrm{~min}$ at each site. Large patches of each focal species were selected for observation. Within this larger patch, an area with $1-\mathrm{m}$ radius $\left(3.14 \mathrm{~m}^{2}\right)$ was selected where flower visitor identity and frequency were recorded and the number of focal flowers counted. Visitation was expressed as visits flower ${ }^{-1} \mathrm{~h}^{-1}$. Observations of native species in the invaded plot took place $<30 \mathrm{~m}$ from the nearest patch of $A$. saligna. Flower visitors not identifiable to species by eye in the field were collected for later identification. Time spent collecting flower visitors was not included in overall observation time, and visitors were collected using 'fynbos forceps' - consisting of two tea strainers tied to the end of a large pair of tongs - rather than sweep netting as the former causes less disruption. Floral visits were counted only if visitors made contact with the flower's reproductive parts, potentially transferring pollen.

\subsection{Data analyses}

To test whether unequal floral densities of focal species influenced flower visitation patterns between invaded and uninvaded plots, we quantified floral display size in invaded and uninvaded areas. We recorded number of floral displays, area of floral displays, number of floral 'units' per floral display and number of floral units per observation area within $30-50 \mathrm{~m}$ radius of each observation area (Appendix A). A floral display comprised a recognizable visual unit of conspecific flowers and referred to a single flower or group of flowers depending on the species (sensu Hegland and Totland, 2005). Floral display area was measured as the size of the flowering plant patch using one of three formulae: $\pi r^{2}$ if circular and vertically flat; length $x$ width if rectangular; or $\pi r^{2}+2 \pi r^{2}$ if circular with a depth dimension. A floral unit is a single flower head, or part of a multiple head, from which a medium size bee has to fly rather than walk to reach another floral unit of the same species (Dicks et al., 2002). We statistically compared floral parameters between all invaded and all uninvaded plots using the paired Wilcoxon signed rank test. We used $\mathrm{R}$ for all statistical analyses (R Development Core Team, 2011).

We compared insect visitation rate to focal species at invaded and uninvaded sites, where visitation rate is the number of visits flower ${ }^{-1} h^{-1}$. We use visitation rate to account for the effect of floral density on visitation frequency. Because our data were non-parametric and contain many zeroes, we compared visitation rates of all flower visitors to all focal species across sites, each major flower visitor group to all focal species across all sites, and all flower visitors to individual focal species at each site, using a paired Wilcoxon signed rank test. Because sample sizes differed for focal species between field seasons (see Appendix B), we calculated one median visitation rate for each focal species $(N=12)$ when testing visitation differences of all focal species between invaded and uninvaded sites (Appendix C). We used individual focal species observations to calculate differences in visitation to individual focal species between invaded and uninvaded plots (Appendix B). We calculated functional group composition as the proportion of the total visitation rate comprised by each visitor group.

To test if field site was independent from difference in visitation rate to focal species between invaded and uninvaded plots, we used a generalized linear model with a Gaussian distribution and identity link because difference in visitation rate was normally distributed (Shapiro Wilk $W=0.964, P=0.762$ ). We divided flower visitors into groups based on their general functional differences, which, based on the subset of species we observed, refers to: beetles, flies, bees (small bees and native honeybees), other hymenoptera (wasps and ants), and other (all other insects). We did not group below family level for analyses involving visitation rate, as there were not enough representative individuals from each subgroup.

To find the flower visitor overlap of each focal species and A. saligna, we calculated the proportion of total visitation rate to a focal species that was comprised of visitor groups that also visited A. saligna. Flower visitor overlap was calculated on both a family- and morphospecies-level. Our sampling periods at each site resulted in unsaturated species-accumulation curves (not shown), thus we do not compare species richness or diversity between invaded and uninvaded sites. Because consecutive visits of most (non-bee) flower visitors were either non-existent or difficult to count, visitor abundance closely mirrored visitation frequency so visitor abundance is not reported here.

\section{Results}

Overall flower density parameters were not significantly different between invaded and uninvaded plots across all sites (Appendix D). However, at Mamre, there were significantly more floral displays $(N=9 ; V=33 ; P=0.042)$ and lower floral unit density $(N=9 ; V=1 ; P=0.008)$ for all focal species pooled at invaded plots than at uninvaded plots. Floral unit density of Muraltia satureioides was significantly higher $(N=3 ; V=21 ; P=0.031)$ and number of floral displays was nearly significantly lower $(N=3$; $V=0 ; P=0.057)$ at invaded plots. 
Table 1

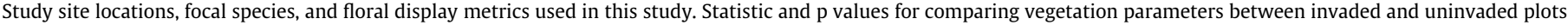
can be found in Appendix D.

\begin{tabular}{|c|c|c|c|c|c|c|c|c|c|}
\hline \multirow[t]{2}{*}{ Study site } & \multirow[t]{2}{*}{ GPS location } & \multirow[t]{2}{*}{ Focal species } & \multirow[t]{2}{*}{ Family } & \multicolumn{2}{|c|}{$\begin{array}{l}\text { Median \# floral } \\
\text { displays/plot }\end{array}$} & \multicolumn{2}{|c|}{$\begin{array}{l}\text { Median area/floral } \\
\text { display }\left(\mathrm{m}^{2}\right)\end{array}$} & \multicolumn{2}{|c|}{$\begin{array}{l}\text { Median floral unit } \\
\text { density } / \mathrm{m}^{2}\end{array}$} \\
\hline & & & & Invaded & Uninvaded & Invaded & Uninvaded & Invaded & Uninvaded \\
\hline \multirow[t]{3}{*}{ Mamre } & $33^{\circ} 31.3 \mathrm{~S}$ & Dimorphotheca pluvialis (L.) Moench & Asteraceae & 38 & 17 & 14.2 & 12.8 & 6.37 & 22.8 \\
\hline & $18^{\circ} 29.2 \mathrm{E}$ & Polycarena lilacina Hilliard & Scrophulariaceae & 36 & 1 & 2.47 & 7610 & 17.2 & 134 \\
\hline & & Ursinia anthemoides (L.) Poir. & Asteraceae & 1 & 10 & 4900 & 2480 & 13.1 & 48.6 \\
\hline \multirow[t]{3}{*}{ Koude Vlakte } & $34^{\circ} 28.5 \mathrm{~S}$ & Chrysanthemoides monilifera & Asteraceae & 19.5 & 14.5 & 15.2 & 15.4 & 44.9 & 104 \\
\hline & $19^{\circ} 26.7 \mathrm{E}$ & Muraltia satureioides DC. & Polygalaceae & 8.5 & 14 & 60.5 & 18.9 & 94.4 & 46.2 \\
\hline & & Roepera fulva (L.) Beier and Thulin & Zygophyllaceae & 8.5 & 9 & 2.15 & 1.71 & 206 & 185 \\
\hline \multirow[t]{3}{*}{ Witkrans } & $34^{\circ} 33.2 \mathrm{~S}$ & Erica parviflora L. complex & Ericaceae & 6 & 22 & 64.9 & 56.3 & 107 & 458 \\
\hline & $19^{\circ} 27.5 \mathrm{E}$ & Leucospermum patersonii (L.) E.Phillips & Proteaceae & 13 & 17 & 5.69 & 20.5 & 7.96 & 16.4 \\
\hline & & Pelargonium betulinum (L.) L'Hér. & Geraniaceae & 14 & 16 & 1.7 & 2.51 & 9.9 & 13 \\
\hline \multirow[t]{3}{*}{ Walshacres } & $34^{\circ} 25.0 \mathrm{~S}$ & Erica imbricata L. complex & Ericaceae & 65 & 25 & 11.2 & 75.8 & 93.9 & 80.6 \\
\hline & $19^{\circ} 25.9 \mathrm{E}$ & Cyphia volubilis (Burm.f.) Willd. & Campanuleaceae & 28 & 46 & 0.031 & 0.083 & 191 & 103 \\
\hline & & Mimetes cucullatus (L.) R.Br. & Proteaceae & 38 & 8 & 4.69 & 6.61 & 2.86 & 5.09 \\
\hline Penhill & $\begin{array}{l}33^{\circ} 59.4 \mathrm{~S} \\
18^{\circ} 44.6 \mathrm{E}\end{array}$ & Acacia saligna (Labill.) H.L. Wendl. & Fabaceae & $\mathrm{n} / \mathrm{a}$ & $\mathrm{n} / \mathrm{a}$ & $\mathrm{n} / \mathrm{a}$ & $\mathrm{n} / \mathrm{a}$ & $\mathrm{n} / \mathrm{a}$ & $\mathrm{n} / \mathrm{a}$ \\
\hline
\end{tabular}

\subsection{Paired tests}

We found no significant difference in visitation rate of all insects or of individual visitor groups to focal species across all sites (Table 2). When testing for differences of flower visitors to individual focal species at each site, we found that visitation rates of all insects and bees were significantly higher to Roepera fulva at uninvaded sites (Table 2). Beetle visitation to Leucospermum patersonii was marginally higher at invaded versus uninvaded plots. The proportion of overall visitation rate comprised by each visitor group at all invaded and uninvaded sites is presented in Fig. 2. No significant differences were found between invaded and uninvaded sites for any group (chi-squared $=0.396, d f=5, P=0.995$ ).

Results of the generalized linear model indicated that site had no effect on change in visitation rate of all visitor groups between invaded and uninvaded plots.

\subsection{Acacia flower visitors}

A. saligna was visited most frequently by beetles ( $60 \%$ of total visitation rate; $\operatorname{avg}=0.145 \pm 0.021$ visits flower ${ }^{-1} \mathrm{~h}^{-1}$ ), followed by native honeybees ( $A$. mellifera subsp. capensis; $26 \%$ of total visitation rate; avg $=0.061 \pm 0.023$ visits flower $\left.{ }^{-1} \mathrm{~h}^{-1}\right)$ and flies $(9 \%$ of total visitation rate; $a v g=0.023 \pm 0.006$ visits flower $^{-1} \mathrm{~h}^{-1}$ ) across all sites (including the Acacia-only site, Penhill; Fig. 3). The families Nitidulidae, Mordellidae, Melyridae, and Scarabaeidae comprised $61 \%$ of all beetle visits, and calyptrate flies (mostly from family Rhiniidae) comprised approximately $63 \%$ of all fly visits (Table 3). When comparing flower visitor composition on A. saligna inflorescences between sites, proportion of visits made by major visitor groups (beetles, flies, and honeybees) differed markedly (chi-squared $=233, d f=10, P<2.2 \mathrm{e}-16$; Fig. 4). At Mamre, where honeybees were absent during our survey, about $40 \%$ of the total visitation rate to $A$. saligna was made by Diptera, mainly of family Rhiniidae, and about $60 \%$ by small beetles of five main families (Melandryidae, Anthicidae, Mordellidae, Nitidulidae, and Melyridae). Visitor group proportions were roughly similar at Koude Vlakte (both years) and Witkrans, but were dominated at Walschacres by beetles from families Nitidulidae and Tenebrionidae and at Penhill by beetles in the families Scarabaeidae, Mordellidae, and Melyridae. A list of all visitors to A. saligna can be found in Table 3 . Additionally, $26 \%$ of the total visitation rate to A. saligna inflorescences was made by flower visitors (39/56 morphospecies) not found on any of the focal species across all sites (see Appendix E).

\subsection{Flower visitor overlap with A. saligna}

Flower visitor overlap with $A$. saligna was highest in the native plant species $R$. fulva (88\% of total visitation rate, 2009 field season), and Pelargonium betulinum (61\%), mainly due to the shared flower visitor A. mellifera subsp. capensis (Appendix E). Overlap at the family level was highest with R. fulva (95\%, 2009 field season), Dimorphotheca pluvialis (91\%), L. patersonii (87\%), and R. fulva (83\%, 2010 field season) due to sharing of the families Apidae, Bombyliidae and Scraptiidae, Formicidae and Apidae, and Apidae, respectively.

\section{Discussion}

Visitation rates of all insects and bees to the focal species $R$. fulva (Fig. 5) were significantly lower in invaded plots than in uninvaded plots in both years of our study, removing the possibility that $A$. saligna invasion acts to increase overall resource availability and faciliate visitation to native species. Results also suggest that $R$. fulva may suffer from floral competition with A. saligna. The fact that honeybees were found to visit $A$. saligna inflorescences frequently further supports the idea that the alien's overwhelming floral display at invaded sites could be attracting bee visits away from $R$. fulva. In contrast, a higher beetle visitation rate to Leucospermum patersonii at invaded plots could indicate a facilitative interaction with A. saligna. However, this is less likely as beetles are not suggested to be an important visitor group in terms of proportion of total visitation rate to $L$. patersonii (Appendix E) and were largely sedentary, moving little between flowers (excluding Scarabaeidae: Hopliini beetles).

The high number of beetles found visiting A. saligna inflorescences is likely inflated because this number included small beetles that were present on the flowers before the observation began and remained on or in the inflorescences during the observation. Thus, most of the beetle individuals counted were sedentary or moved within the same inflorescence during the course of our observation. This does not discount their importance as potential pollinators. The most important visitors to A. saligna inflorescences are probably native honeybees, as they are the most frequent and mobile flower visitors. This is in line with other studies of Australian Acacia flower visitors in the plants' introduced ranges (Alves and Marins-Corder, 2009; Sornsathapornkul and Owens, 1998; J.G. Rodger, unpubl. data) and suggests that honeybees may be important in cross-pollination (Stone et al., 2003), though this remains to be formally tested. Our results also concur with a growing body of 
literature reporting the importance of honeybees in the pollination and spread of invasive flowering plants (Barthell et al., 2001; Gross et al., 2010; Richardson et al., 2000a; Stout et al., 2002). Our observations of the broad spectrum of visitors to $A$. saligna adds support for the idea that the spread of invasive plant species is often not limited by a lack of suitable pollinators (Richardson et al., 2000a). Strong interactions between the native honeybee, A. mellifera subsp. capensis, and A. saligna are of concern because the honeybee is a generalist and visits many flowering fynbos species. Thus, usurpation of this pollinator by A. saligna could have far-reaching effects in the native plant community and significantly alter pollination network structure (Aizen et al., 2008). Interactions between farmed honeybees and flowering $A$. saligna are important to consider as they contribute to total Acacia visitation and could contribute toward Acacia pollination and reproduction success. Similarly, A. saligna could be providing farmed honeybee populations with an important forage resource.

The finding of different Acacia flower visitor assemblages between sites may reflect site differences in vegetation type, structure, and native species richness. Variation in visitor assemblage further highlights the lack of specificity in A. saligna's relations with flower visitors. We recommend that future studies investigate the consequences of such variation for Acacia seed set. The fact that the majority of morphospecies found on A. saligna inflorescences were not found on any of the focal species would suggest low potential flower visitor overlap; however, $30 \%$ of the total visitation rate to $A$. saligna was comprised by native honeybees, which also visited many of the focal species. Therefore, flower visitor overlap was still relatively high based on a shared generalist flower visitor.R. fulva had by far the highest morphospecies overlap with $A$. saligna compared to other focal species, indicating that this species may be vulnerable to changes in flower visitation when $A$. saligna is present. This prediction is supported by our results from the Wilcoxon's paired test that showed a significantly lower visitation rate of insects to this focal species when A. saligna was present across both years. The fact that flower visitor overlap between $R$. fulva and $A$. saligna is driven primarily by the native honeybee has important implications for other native species that are frequently visited by honeybees. In addition to reduced visitation rates, species that share honeybees with $A$. saligna may suffer from improper

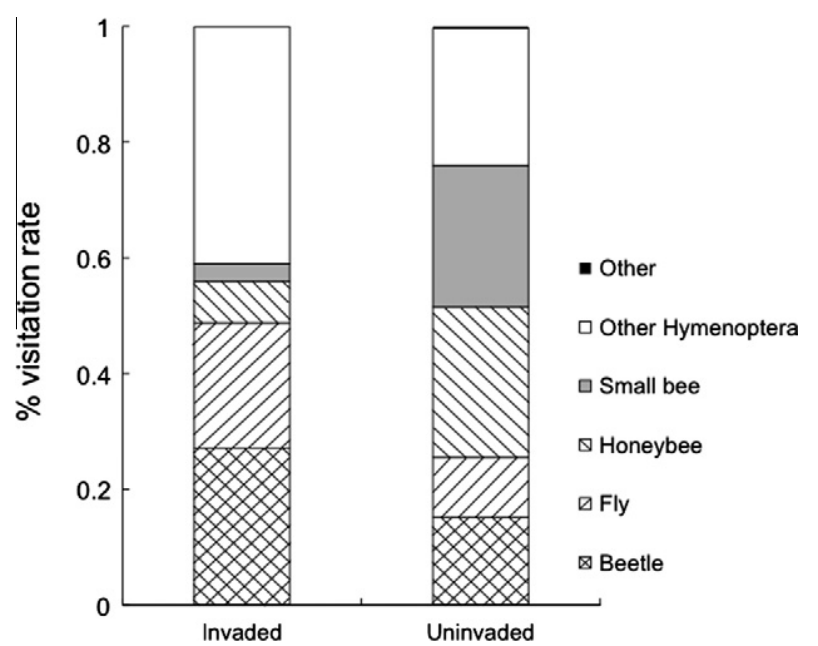

Fig. 2. Composition of flower visitor groups observed on focal native species in invaded and uninvaded plots showing the proportion of total visitation rate (visits flower ${ }^{-1} \mathrm{~h}^{-1}$ ) comprised by each group.

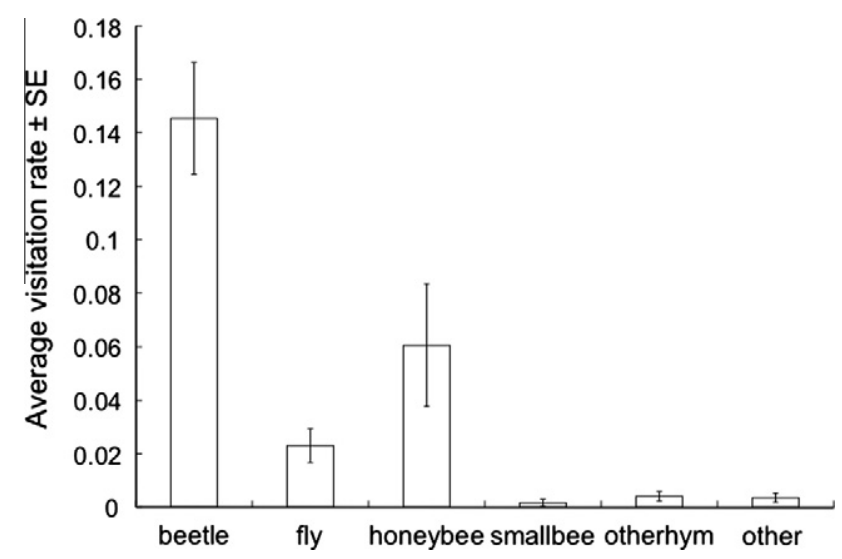

Fig. 3. Average visitation rates (visits flower ${ }^{-1} h^{-1}$ ) of flower visitor groups to Acacia saligna. otherhym $=$ other hymenoptera.

Table 2

Wilcoxon ranked sum test results comparing visitation rate between invaded (I) and uninvaded (U) plots. Only significant results are presented.

\begin{tabular}{|c|c|c|c|c|c|}
\hline \multicolumn{3}{|c|}{ Variables tested between invaded and uninvaded plots } & \multicolumn{2}{|c|}{ Median visitation rate (visits flower ${ }^{-1} \mathrm{~h}^{-1}$ ) } & \multirow[b]{2}{*}{ Result } \\
\hline Focal species & Visitor group & $N$ & I & $\mathrm{U}$ & \\
\hline \multirow[t]{6}{*}{ All } & All & 12 & 0.31 & 0.23 & $\begin{array}{l}V=46 \\
P=0.622\end{array}$ \\
\hline & Beetles & 12 & 0.079 & 0.009 & $\begin{array}{l}V=53 \\
P=0.301\end{array}$ \\
\hline & Flies & 12 & 0.047 & 0.034 & $\begin{array}{l}V=51 \\
P=0.380\end{array}$ \\
\hline & Honeybees & 12 & 0.089 & 0.179 & $\begin{array}{l}V=8 \\
P=0.375\end{array}$ \\
\hline & Small bees & 12 & 0.027 & 0.063 & $\begin{array}{l}V=11.5 \\
P=0.400\end{array}$ \\
\hline & Other hymenoptera & 12 & 0.019 & 0.018 & $\begin{array}{l}V=33 \\
P=0.25\end{array}$ \\
\hline Roepera fulva (2009 and 2010) & All & 9 & 0.476 & 0.879 & $\begin{array}{l}V=3 \\
P=0.020\end{array}$ \\
\hline Roepera fulva (2009 and 2010) & Honeybees & 9 & 0.011 & 0.86 & $\begin{array}{l}V=7 \\
P=0.074\end{array}$ \\
\hline Roepera fulva (2009 and 2010) & All bees & 9 & 0.234 & 0.875 & $\begin{array}{l}V=5 \\
P=0.039\end{array}$ \\
\hline Erica parviflora & Honeybees & 6 & 0.089 & 0 & $\begin{array}{l}V=20 \\
P=0.063\end{array}$ \\
\hline Leucospermum patersonii & Beetles & 5 & 0.235 & 0 & $\begin{array}{l}V=15 \\
P=0.059\end{array}$ \\
\hline
\end{tabular}


Table 3

List of flower visitors to Acacia saligna at five study sites in the Western Cape, South Africa.\% columns refer to (left to right): the proportion of all visits made by the given visitor order; the proportion of all order visits made by the given visitor family.

\begin{tabular}{|c|c|c|c|c|}
\hline Order & $\%$ of total visits & Family & $\%$ of order visits & Morphospecies \\
\hline \multirow[t]{12}{*}{ Coleoptera } & 61.6 & Anthicidae & 5.68 & $\begin{array}{l}\text { Anthicus sp. } \\
\text { Formicomus sp. } \\
\text { Notoxus sp. }\end{array}$ \\
\hline & & Bruchidae & 0.20 & Bruchidae sp. \\
\hline & & Chrysomelidae & 1.76 & $\begin{array}{l}\text { Cryptocephalinae sp. } \\
\text { Eumolpinae sp. } \\
\text { Galerucinae sp. } 1 \\
\text { Galerucinae sp. } 2 \\
\text { Galerucinae sp. } 3\end{array}$ \\
\hline & & Cryptophagidae & 0.39 & $\begin{array}{l}\text { Cryptophagidae sp. '18' } \\
\text { Cryptophagidae sp. 'cry' }\end{array}$ \\
\hline & & Curculionidae & 4.31 & $\begin{array}{l}\text { Unidentified } \\
\text { Melanterius sp. (control agent) } \\
\text { Ceutorhynchini sp. } \\
\text { Ceutorhynchus sp. } 1 \\
\text { Ceutorhynchus sp. } 2 \\
\text { Derolomus sp. } \\
\text { Tychius sp. }\end{array}$ \\
\hline & & Dermestidae & 2.94 & $\begin{array}{l}\text { Dermestidae sp. '7' } \\
\text { Dermestidae sp. '7A' } \\
\text { Dermestidae sp. '7C' } \\
\text { Anthrenus sp. }\end{array}$ \\
\hline & & Elateridae & 0.98 & Calais sp. \\
\hline & & Melandryidae & 7.63 & Melandryidae sp. \\
\hline & & Melyridae & 13.5 & $\begin{array}{l}\text { Melyridae sp. '8' } \\
\text { Melyridae sp. '8-1' } \\
\text { Melyridae sp. '9' } \\
\text { Melyridae sp. 'M }\end{array}$ \\
\hline & & Mordellidae & 16.4 & $\begin{array}{l}\text { Unidentified } \\
\text { Anaspis sp. } 1 \\
\text { Anaspis sp. } 2 \\
\text { Anaspis sp. } 3 \\
\text { Anaspis sp.4 }\end{array}$ \\
\hline & & Nitidulidae & 21.1 & $\begin{array}{l}\text { Unidentified } \\
\text { Aethina sp. } \\
\text { Carpophilus sp. } \\
\text { Meligethes sp. } \\
\text { Pria sp. }\end{array}$ \\
\hline & & Scarabaeidae & 10.0 & Unidentified \\
\hline \multirow[t]{4}{*}{ Coleoptera } & & Scarabaeidae & & $\begin{array}{l}\text { Rutelinae: Hopliini misc } \\
\text { Rutelinae: Hopliini sp. ' } 10 \mathrm{C} \text { ' } \\
\text { Rutelinae: Hopliini sp. '10S2' } \\
\text { Rutelinae: Hopliini sp. 'black and white' } \\
\text { Rutelinae: Hopliini sp. 'orange' }\end{array}$ \\
\hline & & Scraptiidae & 1.17 & $\begin{array}{l}\text { Scraptiidae sp. '1' } \\
\text { Scraptiidae sp. '1A' }\end{array}$ \\
\hline & & Tenebrionidae & 7.44 & Statira sp. \\
\hline & & Unidentified & 6.46 & \\
\hline \multirow[t]{11}{*}{ Diptera } & 8.09 & Bibionidae & 1.49 & Bibionidae sp. 'Bib4' \\
\hline & & Bombyliidae & 5.97 & $\begin{array}{l}\text { Unidentified } \\
\text { Bombyliidae sp. } 4 \\
\text { Bombyliidae sp. } 6\end{array}$ \\
\hline & & Calliphoridae & 2.99 & $\begin{array}{l}\text { Unidentified } \\
\text { Calliphoridae sp. ‘4B' }\end{array}$ \\
\hline & & Cecidomyiidae & 5.97 & Cecidomyiidae sp. '6' \\
\hline & & Empididae & 2.99 & $\begin{array}{l}\text { Unidentified } \\
\text { Empididae sp. 'E' }\end{array}$ \\
\hline & & Muscidae & 1.49 & Muscidae sp. '4C' \\
\hline & & Phoridae & 1.49 & Phoridae sp. 'P' \\
\hline & & Rhiniidae & 56.7 & $\begin{array}{l}\text { Rhiniidae sp. } 1 \\
\text { Rhiniidae sp. } 2 \\
\text { Cosmina sp. }\end{array}$ \\
\hline & & Scathophagidae & 1.49 & Scathophadidae sp. \\
\hline & & Sciaridae & 5.97 & Sciaridae sp. '7' \\
\hline & & Unidentified & 13.4 & \\
\hline \multirow[t]{3}{*}{ Hemiptera } & 0.60 & Anthocoridae & 60.0 & Anthocoridae sp. 'anth' \\
\hline & & Rhopalidae & 20.0 & Rhopalidae sp.1 \\
\hline & & Unidentified & 20.0 & \\
\hline \multirow[t]{3}{*}{ Hymenoptera } & 28.5 & Apidae & 94.1 & $\begin{array}{l}\text { Apis mellifera subsp. capensis } \\
\text { Braunsapis sp. }\end{array}$ \\
\hline & & Eulophidae & 0.85 & Tetrastichus sp. \\
\hline & & Formicidae & 1.69 & $\begin{array}{l}\text { Camponotus niveosetosus } \\
\text { Tetraponera sp.1 }\end{array}$ \\
\hline
\end{tabular}


Table 3 (continued)

\begin{tabular}{|c|c|c|c|c|}
\hline Order & $\%$ of total visits & Family & $\%$ of order visits & Morphospecies \\
\hline & & Halictidae & 0.42 & Lasioglossum sp. \\
\hline & & Platygastridae & 0.42 & Platygastridae sp. \\
\hline & & Unidentified & 2.54 & \\
\hline Lepidoptera & 0.36 & Unidentified & 100 & \\
\hline Thysanoptera & 0.85 & Unidentified & 100 & \\
\hline
\end{tabular}

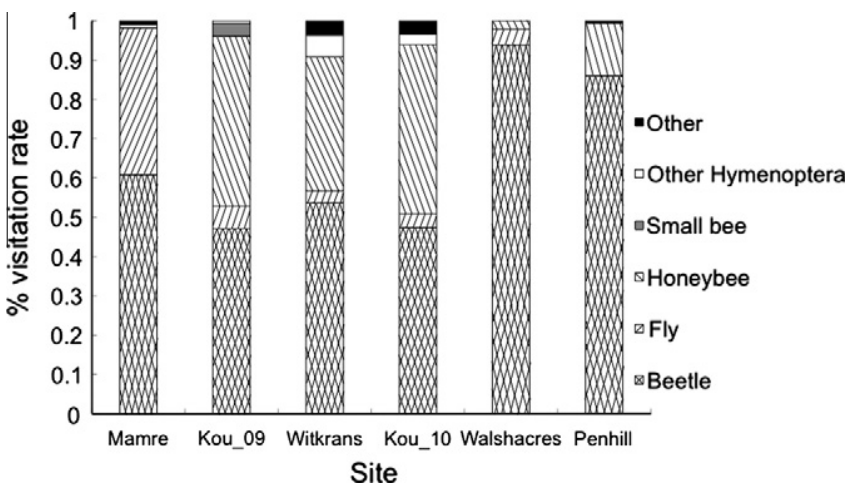

Fig. 4. Composition of flower visitor groups found on Acacia saligna at each study site showing the proportion of total visitation rate (visits flower ${ }^{-1} \mathrm{~h}^{-1}$ ) comprised by each group.

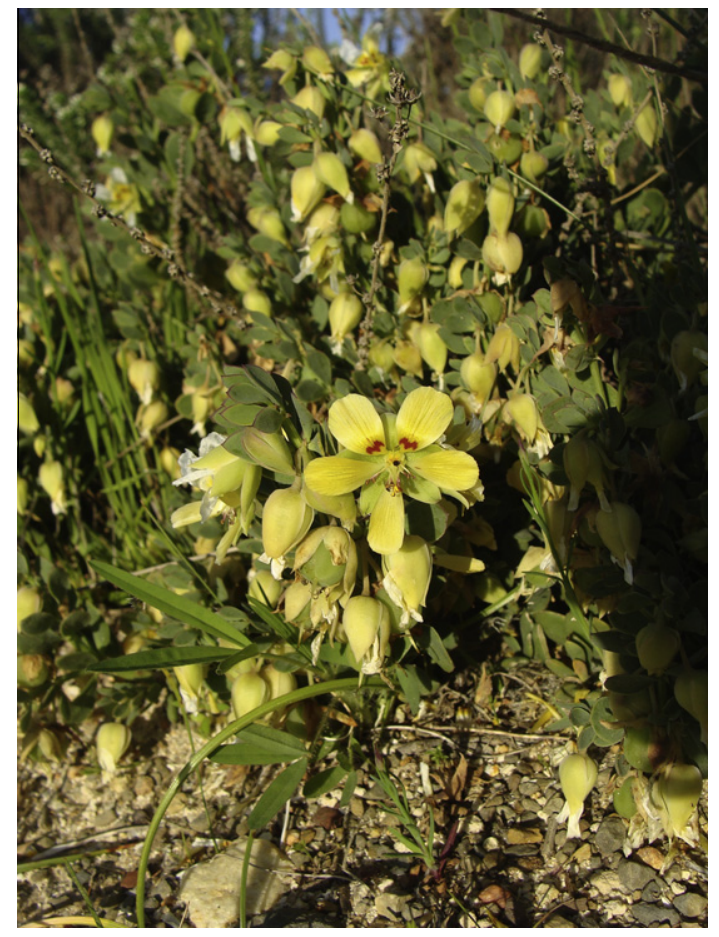

Fig. 5. The focal native species, Roepera fulva, at the Koude Vlakte field site had the highest flower visitor overlap with Acacia saligna primarily due to the shared visitor Apis mellifera subsp. capensis, the native honeybee (photo: M.R. Gibson).

pollen transfer resulting in stigma clogging and pollen loss to heterospecific stigmas (Larson et al., 2006). These latter effects are an interesting avenue for future research on the effects of $A$. saligna on native flowering plants.

\section{Conclusions}

The effect of $A$. saligna on insect visitation to co-flowering taxa was both species- and site-specific in our study. Consequently, we suggest that drawing conclusions on A. saligna's effect on natives at a community level requires further investigation. However, the strong effect of $A$. saligna on honeybee visitation rates at coflowering natives suggests that Acacia invasion may have widereaching impacts on the pollination and reproductive success of many co-flowering native communities, especially since bees are the most important pollinators for many flowering species (Faegri and van der Pijl, 1979; Johnson, 2004). Additional measurements of the effect of $A$. saligna on interspecific pollen transfer within native communities, and its effect on seed set in native species, are needed. Furthermore, honeybees are generalist foragers that can facilitate the invasion of flowering alien plants (Gross et al., 2010), and more research is needed to determine their contribution to $A$. saligna pollination and reproductive success.

\section{Acknowledgements}

We acknowledge financial support from the DST-NRF Centre of Excellence for Invasion Biology and the Working for Water Programme (through their collaborative project on "Research for Integrated Management of Invasive Alien Species") and the Department of Botany and Zoology at Stellenbosch University. DMR acknowledges additional funding from the National Research Foundation and the Hans Sigrist Foundation. Matimba Bolyi, Frank Chidawanyika and Andrew M. Rogers are thanked for assistance in the field. Simon van Noort, Ashley Kirk-Spriggs, Connal Eardley, and Şerban Procheş kindly assisted for insect identifications and the Compton Herbarium at Kirstenbosch Gardens helped with plant identifications. Landowners of Bilton Wine Estate, Donovan Kirkwood, Simon and Shawn Graff, Russell of Walshacres, Mamre Nature Reserve, Shawn and Michelle Privett, and Steyn Marais of Jakkalsfontein Nature Reserve kindly granted permission to work on their land.

\section{Appendix A. Supplementary material}

Supplementary data associated with this article can be found, in the online version, at http://dx.doi.org/10.1016/j.biocon.2012. 07.011.

\section{References}

Aizen, M.A., Morales, C.L., Morales, J.M., 2008. Invasive mutualists erode native pollination webs. PLoS Biol. 6, 396-403.

Alarcón, R., 2009. Congruence between visitation and pollen transport networks in a California plant-pollinator community. Oikos 119, 35-44.

Alves, E.M.S., Marins-Corder, M.P., 2009. Reproductive biology of Acacia mearnsii De Wild. (Fabaceae) IV: flower visitors. Rev. Arvore. 33, 443-450.

Barthell, J.F., Randall, J.M., Thorp, R.W., Wenner, A.M., 2001. Promotion of seed set in yellow star-thistle by honey bees: evidence of an invasive mutualism. Ecol. Appl. 11, 1870-1883.

Bartomeus, I., Vila, M., Santamaria, L., 2008. Contrasting effects of invasive plants in plant-pollinator networks. Oecologia 155, 761-770.

Bernhardt, P., 1989. The floral biology of Australian Acacia. In: Stirton, C.H. Zarucchi, J.L. (Eds.), Advances in Legume Biology. Missouri Botanical Garden, St. Louis, Missouri, pp. 263-281.

Carvalheiro, L.G., Barbosa, E.R.M., Memmott, J., 2008. Pollinator networks, alien species and the conservation of rare plants: Trinia glauca as a case study. J. Appl. Ecol. 45, 1419-1427.

Dicks, L.V., Corbet, S.A., Pywell, R.F., 2002. Compartmentalization in plant-insect flower visitor webs. J. Anim. Ecol., 32-43. 
Faegri, K., van der Pijl, L., 1979. The Principles of Pollination Ecology, third ed. Pergamon Press, Oxford, UK.

Gaertner, M., den Breeÿen, A., Hui, C., Richardson, D.M., 2009. Impacts of alien plant invasions on species richness in Mediterranean-type ecosystems: a metaanalysis. Prog. Phys. Geog. 33, 319-338.

Gaertner, M., Richardson, D.M., Privett, S.D.J., 2011. Effects of alien plants on ecosystem structure and functioning and implications for restoration: insights from three degraded sites in South African Fynbos. Environ. Manage. 48, 57-69.

Geerts, S., Pauw, A., 2009. African sunbirds hover to pollinate an invasive hummingbird-pollinated plant. Oikos 118, 573-579.

George, N., Byrne, M., Yan, G., 2009. Observations of the reproductive biology of Acacia saligna (Labill.) H.L. Wendl. J. Roy. Soc. West. Aust. 92, 5-14.

Gibson, M.R., Richardson, D.M., Marchante, E., Marchante, H., Rodger, J.G., Stone, G.N., Byrne, M., Fuentes-Ramírez, A., George, N., Harris, C., Johnson, S.D., Le Roux, J.J., Miller, J.T., Murphy, D.J., Pauw, A., Prescott, M.N., Wandrag, E.M., Wilson, J.R.U., 2011. Reproductive biology of Australian acacias: important mediator of invasiveness? Divers. Distrib. 17, 911-933.

Godoy, O., Richardson, D.M., Valladares, F., Castro-Díez, P., 2009. Flowering phenology of invasive alien plant species compared with native species in three Mediterranean-type ecosystems. Ann. Bot. 103, 485-494.

Gross, C.L., Gorrell, L., Macdonald, M.J., Fatemi, M., 2010. Honeybees facilitate the invasion of Phyla canescens (Verbenaceae) in Australia - no bees, no seed! Weed Res. 50, 364-372.

Hegland, S.J., Totland, Ø., 2005. Relationships between species' floral traits and pollinator visitation in a temperate grassland. Oecologia 145, 586-594.

Henderson, L., 2001. Alien Weeds and Invasive Plants. A complete guide to declared weeds and invaders in South Africa. Agricultural Research Council of South Africa, Pretoria, South Africa.

Johnson, S.D., 2004. An overview of plant-pollinator relationships in southern Africa. Int. J. Trop. Insect Sci. 24, 45-54.

Johnson, S.D., Linder, H.P., Steiner, K.E., 1998. Phylogeny and radiation of pollination systems in Disa (Orchidaceae). Am. J. Bot. 85, 402-411.

Lamarque, L.J., Delzon, S., Lortie, C.J., 2011. Tree invasions: a comparative test of the dominant hypotheses and functional traits. Biol. Invasions 13, 1969-1989.

Larson, D.L., Royer, R.A., Royer, M.R., 2006. Insect visitation and pollen deposition in an invaded prairie plant community. Biol. Conserv. 130, 148-159.

Levy, S., 2011. The pollinator crisis: what's best for bees. Nature 479, 164-165.

Lopezaraiza-Mikel, M.E., Hayes, R.B., Whalley, M.R., Memmott, J., 2007. The impact of an alien plant on a native plant-pollinator network: an experimental approach. Ecol. Lett. 10, 539-550.

Memmott, J., Waser, N.M., 2002. Integration of alien plants into a native flowerpollinator visitation web. Proc. R. Soc. B 269, 2395-2399.

Moragues, E., Traveset, A., 2005. Effect of Carpobrotus spp. on the pollination success of native plant species of the Balearic Islands. Biol. Conserv. 122, 611-619.

Morales, C.L., Traveset, A., 2009. A meta-analysis of impacts of alien vs. native plants on pollinator visitation and reproductive success of co-flowering native plants. Ecol. Lett. 12, 716-728.

Moroń, D., Lenda, M., Skorka, P., Szentgyorgyi, H., Settele, J., Woyciechowski, M. 2009. Wild pollinator communities are negatively affected by invasion of alien goldenrods in grassland landscapes. Biol. Conserv. 142, 1322-1332.

Mucina, L., Rutherford, M.C., 2006. The Vegetation of South Africa, Lesotho and Swaziland. Strelitzia 19, South African National Biodiversity Institute Pretoria.

Muñoz, A.A., Cavieres, L.A., 2008. The presence of a showy invasive plant disrupts pollinator service and reproductive output in native alpine species only at high densities. J. Ecol. 96, 459-467.

Pimm, S.L., Russell, G.J., Gittleman, J.L., Brooks, T.M., 1995. The future of biodiversity. Science 269, 347.

Poynton, R.J., 2009. Tree Planting in Southern Africa, vol. 3: Other Genera. Pretoria, South Africa.

Pyšek, P., Richardson, D.M., 2010. Invasive species, environmental change and management, and health. Ann. Rev. Environ. Resour. 35, 25-55.

R Development Core Team, 2011. R: A language and environment for statistical computing. R Foundation for Statistical Computing, Vienna, Austria.

Real, L., 1983. Pollination Biology. Academic Press, Orlando, Florida.
Rebelo, A.G., 2001. The state of plants in the Cape Flora. In: Verdoorn, G.H., Le Roux J. (Eds.), The State of South Africa's Species. Endangered Wildlife Trust, Pretoria, pp. 18-43.

Rebelo, A.G., Boucher, C., Helme, N., Mucina, L., Rutherford, M.C., 2006. Fynbos biome. In: Mucina, L., Rutherford, M.C. (Eds.), The vegetation of South Africa, Lesotho and Swaziland. South African National Biodiversity Institute, Pretoria, pp. 53-219.

Richardson, D.M., Allsopp, N., D’Antonio, C.M., Milton, S.J., Rejmánek, M., 2000a. Plant invasions - the role of mutualisms. Biol. Rev. 75, 65-93.

Richardson, D.M., Carruthers, J., Hui, C., Impson, F.A.C., Miller, J.T., Robertson, M.P., Rouget, M., Le Roux, J.J., Wilson, J.R.U., 2011. Human mediated introductions of Australian acacias - a global experiment in biogeography. Divers. Distrib. 17, 771-787.

Richardson, D.M., Pyšek, P., Rejmánek, M., Barbour, M.G., Panetta, F.D., West, C.J., 2000b. Naturalization and invasion of alien plants: concepts and definitions. Divers. Distrib. 6, 93-107.

Richardson, D.M., Rejmánek, M., 2011. Trees and shrubs as invasive alien species - a global review. Divers. Distrib. 17, 788-809.

Rouget, M., Richardson, D.M., Cowling, R.M., Lloyd, J.W., Lombard, A.T., 2003. Current patterns of habitat transformation and future threats to biodiversity in terrestrial ecosystems of the Cape Floristic Region, South Africa. Biol. Conserv. 112, 63-85.

Roura-Pascual, N., Richardson, D.M., Krug R.M., Brown, A, Chapman, R.A., Forsyth, G.G., Le Maitre, D.C., Robertson, M.P., Stafford, L., van Wilgen, B.W., Wannenburgh, A., Wessels, N., 2009. Ecology and management of alien plant invasions in South African fynbos: accommodating key complexities in objective decision making. Biol. Conserv. 142, 1595-1604.

Schlüter, P.M., Ruas, P.M., Kohl, G., Ruas, C.F., Stuessy, T.O.D.F., Paulus, H.F., 2009. Genetic patterns and pollination in Ophrys iricolor and $O$ mesaritica (Orchidaceae): sympatric evolution by pollinator shift. Bot. J. Linn. Soc. 159, 583-598.

Sornsathapornkul, P., Owens, J.N., 1998. Pollination biology in a tropical Acacia hybrid (A. mangium Willd. $\times$ A. auriculiformis A. Cunn. ex Benth.). Ann. Bot. 81, 631-645.

Stone, G.N., Raine, N.E., Prescott, M., Willmer, P.G., 2003. Pollination ecology of acacias (Fabaceae, Mimosoideae). Aust. Syst. Bot. 16, 103-118.

Stout, J.C., Kells, A.R., Goulson, D., 2002. Pollination of the invasive exotic shrub Lupinus arboreus (Fabaceae) by introduced bees in Tasmania. Biol. Conserv. 106, 425-434.

Traveset, A., Richardson, D.M., 2006. Biological invasions as disruptors of plant reproductive mutualisms. Trends Ecol. Evol. 21, 208-216.

Traveset, A., Richardson, D.M., 2011. Mutualisms: key drivers of invasions ... key casualties of invasions. In: Richardson, D.M. (Ed.), Fifty Years of Invasion Ecology. The Legacy of Charles Elton. Wiley-Blackwell, Oxford, pp. 143-160.

Valdovinos, F.S., Ramos-Jiliberto, R., Flores, J.D., Espinoza, C., Lopez, G., 2009. Structure and dynamics of pollination networks: the role of alien plants. Oikos $118,1190-1200$

van Wilgen, B.W., Dyer, C., Hoffmann, J.H., Ivey, P., Le Maitre, D.C., Moore, J.L., Richardson, D.M., Rouget, M., Wannenburgh, A., Wilson, J.R.U., 2011. Nationalscale strategic approaches for managing introduced plants: insights from Australian acacias in South Africa. Divers. Distrib. 17, 1060-1075.

van Wilgen, B.W., Richardson, D.M., 1985. The effects of alien shrub invasions on vegetation structure and fire behaviour in South African fynbos shrublands: a simulation study. J. Appl. Ecol. 22, 955-966.

van Wilgen, B.W., Richardson, D.M., Seydack, A.H.W., 1994. Managing fynbos for biodiversity: constraints and options in a fire-prone environment. S. Afr. J. Sci. $90,322-329$.

Vázquez, D.P., Morris, W.F., Jordano, P., 2005. Interaction frequency as a surrogate for the total effect of animal mutualists on plants. Ecol. Lett. 8, 1088-1094.

Williams, N.M., Cariveau, D., Winfree, R. Kremen, C., 2010. Bees in disturbed habitats use, but do not prefer, alien plants. Basic Appl. Ecol. 12, 332-341.

Yelenik, S.G., Stock, W.D., Richardson, D.M., 2004. Ecosystem level impacts of invasive Acacia saligna in the South African fynbos. Restor. Ecol. 12, 44-51. 